\title{
ANALISIS SPASIO-TEMPORAL KEJADIAN DEMAM BERDARAH DENGUE (DBD) DI KABUPATEN GORONTALO Spatio-Temporal Analysis of Dengue Health Fever (DBD) In Gorontalo District
}

\author{
Masrin Melangi, Arthur Gani Koto ${ }^{2}$, Ivan Taslim ${ }^{3}$ \\ ${ }^{1}$ Sarjan Perogram studi Geografi Universitas Muhammadiyah Gorontalo, Indonesia \\ ${ }^{2,3}$ Program studi Geografi Universitas Muhammadiyah Gorontalo, Indonesia \\ Korespondensi: masrin.melangi@gmail.com
}

\begin{abstract}
Spatial and temporal data and information is very useful in reducing the number of dengue maladies in each region. Including in Kabupaten Gorontalo that do not yet have spatial and temporal information about DHF incidence. The purpose of this research is to analyze data and information of DHF incidence in Gorontalo Regency spasiotemporal. The study was conducted in Gorontalo.An ArcGIS 10.1 software was applied in this study to view descriptive epidemiology presented in the form of maps, and the tables are then described in an overlap with DHF incidence data through geographic information systems (GIS). The results of this study indicate that in the last six years, from 2010 to 2016 Gorontalo District has DHF outbreak in Limboto sub-district, then in 2013-2016 there are 9 districts that have DHF outbreak of Telaga District, Telaga Jaya, Telaga Biru, West Limboto, Tilango, Tibawa, Bilato and Tabongo marked by an increase in cases every year in the Eastern Region of Gorontalo Regency precisely located in the area of Lake Limboto Area. if diverivikasi use Rainfall data, Dengue incidence in Gorontalo District in 2011 until 2015 is not affected by the amount of rainfall but will be different from the incidence of dengue in 2016 which is actually influenced by the amount of rainfall is high.
\end{abstract}

Keywords: spatio-temporal, gis, dengue health fever, gorontalo

\begin{abstract}
Abstrak - Data dan informasi spasial dan temporal sangat berguna dalam upaya mengurangi jumlah kejadain DBD di setiap daerah. Termasuk di Kabupaten Gorontalo yang belum memiliki informasi secara spasial dan temporal mengenai kejadian DBD. Tujuan dari penelitian ini adalah untuk menganalisis data dan informasi kejadian DBD di Kabupaten Gorontalo secara spasio-temporal. Penelitian ini dilakukan di Kabupaten Gorontalo.Sebuah perangkat lunak ArcGS 10.1 diaplikasikan dalam penelitian ini untuk melihat secara epidemiologi deskriptif yang disajikan dalam bentuk peta, dan tabel yang kemudian digambarkan secara tumpang susun dengan data kejadian DBD melalui sistem informasi geografis (SIG). Hasil penelitian ini menunjukkan bahwa dalam enam tahun terakhir, sejak Tahun 2010 hingga Tahun 2016 Kabupaten Gorontalo mengalami KLB DBD di Kecamatan Limboto, kemudian pada tahun 20132016 terdapat 9 Kecamatan yang mengalami KLB DBD yakni Kecamatan Telaga, Telaga Jaya, Telaga Biru, Limboto Barat, Tilango, Tibawa, Bilato dan Tabongo yang ditandai oleh peningkatan kasus pada setiap tahun di Wilayah bagian Timur Kabupaten Gorontalo tepatnya berada di area Kawasan Danau Limboto. jika diverivikasi menggunakan data curah hujan, Kejadian DBD di Kabupaten Gorontalo pada tahun 2011 hingga tahun 2015 tidak dipengaruhi oleh jumlah curah hujan akan tetapi berbeda dengan kejadian DBD pada tahun 2016 yang justru dipengaruhi oleh jumlah curah hujan yang tinggi.
\end{abstract}

Kata kunci: spasio-temporal, sig, demam berdarah dengue, gorontalo 


\section{PENDAHULUAN/INTRODUCTION}

Kondisi iklim di suatu daerah sangat berpengaruh terhadap aspek kehidupan manusia baik dalam hal ekonomi, kebudayaan termasuk kesehatan. Pada iklim tropis misalnya terdapat penyakit yang berkembangbiak melalui vektor biologis yaitu demam berdarah dengue (DBD) dengan perantara nyamuk yang ditentukan oleh unsur iklim diantaranya suhu, kelembaban dan curah hujan, serta faktor lain seperti arah kecepatan angin, kondisi vegetasi, kondisi drainase, kepadatan penduduk dan radiasi matahari (Nucifera et al 2011). DBD merupakan penyakit yang ditularkan oleh virus dengue melalui gigitan nyamuk Aedes aegypti, penyakit ini dapat menyerang semua orang, tidak mengenal usia dan jenis kelamin, akan tetapi kebanyakan menyerang anak-anak, yang dapat mengakibatkan kematian, serta sering menimbulkan kejadian luar biasa atau wabah (Farahiyah, 2014).

Saat ini Penyakit DBD masih menjadi masalah di Indonesia, hal ini mempengaruhi tingginya angka kesakitan (morbiditas) dan angka kematian (mortalitas) yang ditimbulkan. Kejadian DBD di seluruh wilayah Indonesia biasanya berhubungan dengan berbagai faktor risiko, yaitu lingkungan yang masih kondusif untuk terjadinya tempat perindukan nyamuk Aedes, pemahaman masyarakat yang masih terbatas mengenai pentingnya pemberantasan sarang nyamuk (PSN), perluasan daerah endemik akibat perubahan dan manipulasi lingkungan yang terjadi karena urbanisasi dan pembangunan tempat pemukiman baru, serta meningkatnya mobilitas penduduk (KEMENKES RI, 2016). Dalam penanggulangan kejadian DBD di Indonesia biasanya melalui pemberantasan vektor DBD, dengan melakukan beberapa hal yakni diantaranya: Fogging, Abatisasi, Pengawasan kualitas lingkungan, dan Pembersihan Sarang Nyamuk (PSN).

Data Direktorat Pengendalian Penyakit Tular Vektor dan Zoonosis Kementerian Kesehatan pada tahun 2016 menyebutkan hingga akhir Januari tahun ini, kejadian luar biasa (KLB) penyakit DBD dilaporkan ada di 12 Kabupaten dan 3 Kota dari 11 Provinsi di Indonesia, antara lain: Provinsi Banten (Kabupaten Tangerang), Provinsi Sumatera Selatan (Kota Lubuklinggau), Provinsi Bengkulu (Kota Bengkulu), Provinsi Bali (Kota Denpasar dan Kabupaten Gianyar), Provinsi Sulawesi Selatan (Kabupaten Bulukumba, Pangkep, Luwu Utara, dan Wajo), Provinsi Papua Barat (Kabupaten Kaimana), Provinsi Papua (Kabupaten Mappi), Provinsi NTT (Kabupaten Sikka) Provinsi Jawa Tengah (Kabupaten Banyumas), Provinsi Sulawesi Barat (Kabupaten Majene) dan Provinsi Gorontalo, yaitu Kabupaten Gorontalo.

Data tersebut menunjukkan bahwa Kabupaten Gorontalo mengalami Kejadian Luar Biasa (KLB) DBD oleh karena itu penelitian ini menarik untuk diteliti, Dalam beberapa penelitian yang pernah dilakukan ternyata data dan informasi secara spasial dan temporal sangat berguna dalam upaya mengurangi jumlah kejadain DBD di setiap Daerah, dan Kabupaten Gorontalo belum memiliki informasi secara spasial dan temporal mengenai kejadian DBD sehingga itu penulis mengangkat judul "Analisis Spasiotemporal Kejadian Demam Berdarah Dengue (DBD) di Kabupaten Gorontalo"

\section{METODE DAN DATA / METHODS AND DATA}

Penelitian ini tidak menggunakan pengujian hipotesis terhadap variabel yang akan digunakan. Penelitian ini akan mengkaji secara epidemiologi deskriptif dari kejadian DBD yang akan disajikan dalam bentuk tabular (tabel), yang akan digambarkan secara spasial dengan menggunakan perangkat lunak pengolah data spasial atau SIG. Data yang digunakan berupa:

a. Data jumlah penduduk tiap kecamatan di Kabupaten Gorontalo tahun (2010-2015) yang diperoleh dari BPS Kabupaten Gorontalo.

b. Data jumlah penderita penyakit DBD di Kabupaten Gorontalo tahun (2010-2015) yang diperoleh dari Dinas Kesehatan Kabupaten Gorontalo.

c. Data Curah Hujan yang diperoleh melalui stasiun Klimatologi Tilongkabila

Persamaan yang digunakan dalam penelitian ini merupakan persamaan yang dikutip dari Nucifera pada tahun 2011 :

$$
\text { Angka kejadian (IR) }=\frac{\text { Jumlah penderita }}{\text { JumlahPenduduk }} \times 100.000
$$

Klasifikasi tingkat kejadian penyakit DBD dibagi menjadi 3 yaitu tinggi, sedang, dan rendah. Adapun klasifikasi tingkat kejadian penyakit DBD adalah dengan rumus sebagai 
berikut:

- Rendah, apabila IR $<22$

- Sedang, apabila IR = 22-55

- $\quad$ Tinggi, apabila IR $>55$

\section{HASIL DAN PEMB AHASAN}

\section{Kejadian DBD Tahun 2010}

Berdasarkan data sekunder yang diperoleh melalui analisis secara statistik dan spasial dapat dilihat pada Tabel 1 berikut ini:

Tabel 1. Angka kejadian DBD Tahun 2010

\begin{tabular}{|c|c|c|c|}
\hline \multirow{2}{*}{ Kecamatan } & \multirow{2}{*}{ IR DBD } & \multicolumn{2}{|c|}{ Curah Hujan (mm/tahun) } \\
\hline & & Rata-rata & Pos Hujan \\
\hline Limboto & 206 & 147.41 & Stasiun Geofisika \\
\hline Limboto Barat & 30.52 & 192.67 & Stasiun Djalaludin \\
\hline Telaga Biru & 93.17 & 147.42 & Stasiun Geofisika \\
\hline Telaga Jaya & 16.69 & 147.41 & Pos Hujan Tilango \\
\hline Telaga & 43.19 & 147.41 & Stasiun Geofisika \\
\hline Tilango & 26.97 & 147.42 & Pos Hujan Tilango \\
\hline Tibawa & 4.6 & 192.67 & Stasiun Djalaludin \\
\hline Tabongo & 10.41 & 147.42 & Pos Hujan Batudaa \\
\hline Pulubala & 3.81 & 192.67 & Stasiun Djalaludin \\
\hline Motilango & 5.04 & 241.83 & Pos Hujan Boliyohuto \\
\hline Boliyohuto & 0 & 241.83 & Pos Hujan Boliyohuto \\
\hline Biluhu & 0 & 227.75 & Pos Hujan Biluhu \\
\hline Asparaga & 0 & 166.33 & Pos Hujan Tolangohula \\
\hline Tolangohula & 0 & 166.33 & Pos Hujan Tolangohula \\
\hline Batudaa & 0 & 81.75 & Pos Hujan Batuaaa \\
\hline Batudaa Pantai & 0 & 81.75 & Pos Hujan Batuaaa \\
\hline Bongomeme & 0 & 241.83 & Pos Hujan Boliyohuto \\
\hline
\end{tabular}

(Sumber: Hasil Analis is 2017)

Jumlah penduduk kecamatan limboto berjumlah 45.625 jiwa, $\mathrm{CH}$ rata-rata 147,41 $\mathrm{mm} / \mathrm{tahun}$, berdasarkan data pos hujan Stasiun Geofisika Talumelito dengan angka kejadian berjumlah 232,23 per 100.000 penduduk serta Kecamatan Telaga Biru memiliki jumlah penduduk 26.532 jiwa, CH rata-rata $147,41 \mathrm{~mm} /$ tahun yang menggunakan data pos hujan Stasiun Geofisika Talumelito dengan angka kejadian 93,17 per 100.000 penduduk karena berdasarkan hasil wawancara dengan Kepala Stasiun Klimatologi Tilongkabila Bone Bolango Bapak Iryanto Marmin Suwirno, SP beliau mengatakan bahwa Setiap pos hujan dapat mewakili beberapa Daerah di masing0masing Kecamatan yang ada di Kabupaten Gorontalo yang dapat mencakup $10 \mathrm{~km}^{2}$.

Angka Kejadian >22 dan $<55$ per 100.000 (sedang) pada Tabel 2 terdapat pada tiga Kecamatan yakni Limboto Barat yang memiliki jumlah penduduk, 23.477 jiwa, $\mathrm{CH}$ rata-rata 192,67 mm/tahun berdasarkan data pos hujan Stasiun Meteorologi Djalaludin, dengan angka kejadian 30,52 per 100.000 penduduk, kemudian Kecamatan Telaga yang memiliki jumlah penduduk 20.703 jiwa, CH rata-rata $147,41 \mathrm{~mm} /$ tahun yang menggunakan pos hujan Stasiun Geofisika Talumelito dengan angka kejadian 48,3 per 100.000 pendudu sertaKecamatan Tilango yang memiliki jumlah penduduk 12.865 jiwa, $\mathrm{CH}$ rata-rata $147,42 \mathrm{~mm} /$ tahun berdasarkan data pos hujan Tilango dengan angka kejadian 31,09 per 100.000 penduduk.Serta terdapat tujuh Kecamatan yang memiliki $\mathrm{IR}=0$ yang memiliki jumlah penduduk bervariasi (dapat dilihat pada Lampiran 1) dan Jumlah $\mathrm{CH}$ rata-rata yang bervariasi serta pos hujan yang berbeda-beda, (dilihat pada Tabel 1).

Selain data tabular kita juga dapat melihat secara spasial kejadian DBD di Kabupaten Gorontalo pada Gambar 1, nampak bahwa terdapat beberapa Kecamatan yang memiliki warna gradasi yang berbeda. Pada Gambar 1 terlihat dua Kecamatan yang berwarna merah yakni Kecamatan 
Limboto dan Telaga Biru, tiga Kecamatan lainnya berwarna merah kecoklatan yakni diantaranya Kecamatan Limboto Barat, Telaga, dan Tilango, serta beberapa Kecamatan lainnya yang memiliki warna merah muda kurang lebih 11 Kecamatan, selengkapanya dapat dilihat pada Gambar 1 berikut ini:

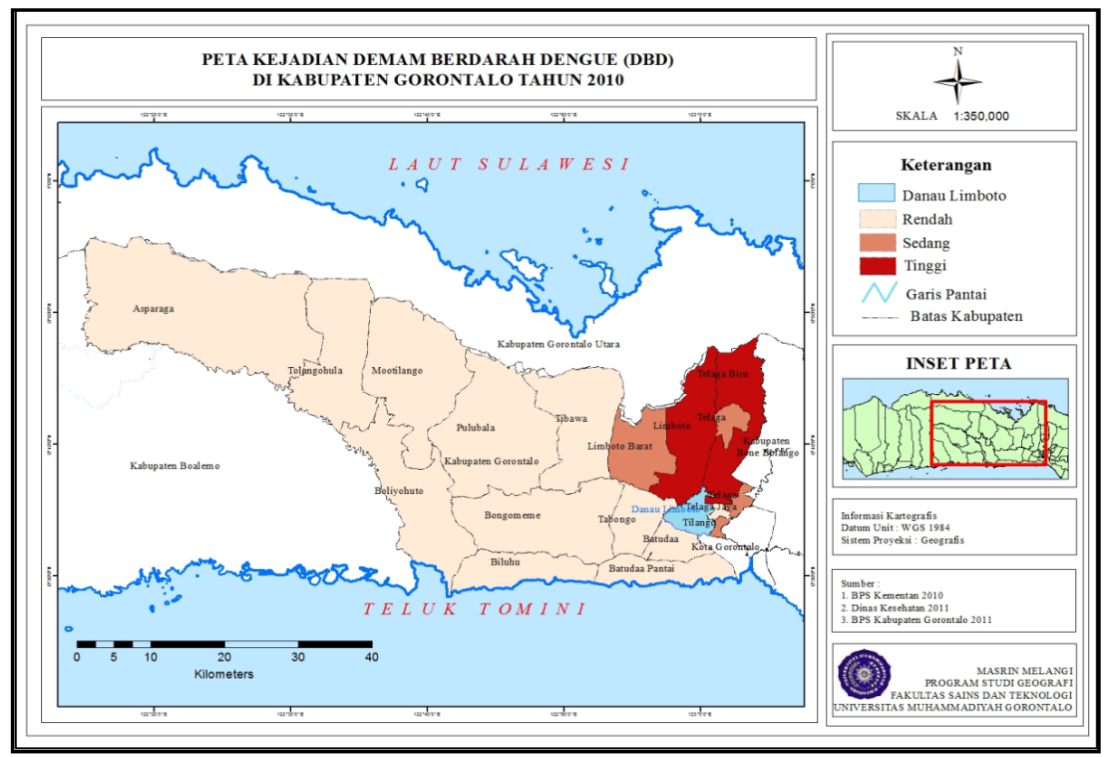

Gambar 1. Peta Kejadian DBD Tahun 2010

\section{Kejadian DBD Tahun 2011}

Berdasarkan data sekunder yang diperoleh melalui analisis secara statistik dan spasial dapat dilihat pada Tabel 2 berikut ini:

Tabel 2. Angka kejadian DBD Tahun 2011

\begin{tabular}{|l|c|c|l|}
\hline \multirow{2}{*}{ Kecamatan } & \multirow{2}{*}{ IR DBD } & \multicolumn{2}{c|}{ Curah Hujan (mm/tahun) } \\
\cline { 3 - 4 } & & Rata-rata & \multicolumn{1}{c|}{ Pos Hujan } \\
\hline Limboto & 1.94 & 95.5 & Stasiun Geofisika \\
\hline Limboto Barat & 11.44 & 192.67 & Stasiun Djalaludin \\
\hline Telaga Biru & 0 & 95.5 & Stasiun Geofisika \\
\hline Telaga Jaya & 0 & 147.41 & Pos Hujan Tilango \\
\hline Telaga & 0 & 128.83 & Pos HujanTelaga \\
\hline Tilango & 0 & 95.5 & Pos Hujan Tilango \\
\hline Tibawa & 0 & 136.92 & Stasiun Djalaludin \\
\hline Tabongo & 0 & 95.5 & Pos Hujan Batudaa \\
\hline Pulubala & 0 & 136.92 & Stasiun Djalaludin \\
\hline Motilango & 0 & 224.75 & Pos Hujan Boliyohuto \\
\hline Boliyohuto & 0 & 224.75 & Pos Hujan Boliyohuto \\
\hline Biluhu & 0 & 149.91 & Pos Hujan Biluhu \\
\hline Asparaga & 0 & 129.5 & Pos Hujan Tolangohula \\
\hline Tolangohula & 0 & 129.5 & Pos Hujan Tolangohula \\
\hline Batudaa & 0 & 71.42 & Pos Hujan Batuaaa \\
\hline Batudaa Pantai & 0 & 71.42 & Pos Hujan Batuaaa \\
\hline Bongomeme & 0 & 224.75 & Pos Hujan Boliyohuto \\
\hline
\end{tabular}

(Sumber: Hasil Analisis 2017)

Tabel 2 menunjukkan bahwa terdapat dua Kecamatan yang memiliki nilai angka kejadian DBD di Kabupaten Gorontalo, dari kedua Kecamatan tersebut memiliki IR $<22$ per 100.000 penduduk yakni Kecamatan Limboto Barat dengan angka Kejadian 11,44 per 100.000 penduduk, yang memiliki jumlah penduduk 25.307 jiwa dan $\mathrm{CH}$ rata-rata 192,67 mm/ tahun yang menggunakan data Stasiun Djalaludin dan Kecamatan Limboto dengan angka kejadian 
1,54 per 100.000 penduduk, yang memiliki jumlah penduduk 48.750 jiwa dan $\mathrm{CH}$ ratarata 95,5 mm/tahun yang menggunakan data Stasiun Geofisika. Namun terdapat di 15 Kecamatan lainnya yang memiliki IR $=0$ yakni Kecamatan Telaga Biru, Telaga Jaya, Telaga, Tilango, Tibawa, Tabongo, Pulubala, Motilango, Boliyohuto, Biluhu, Asparaga, Tolangohula, Batudaa, Batudaa Pantai dan Bongomeme yang memiliki jumlah penduduk bervariasi dan Jumlah $\mathrm{CH}$ rata-rata yang bervariasi serta pos hujan yang berbeda-beda. Selain data tabular kita juga dapat melihat secara spasial kejadian DBD di Kabupaten Gorontalo pada Gambar 2, nampak bahwa Kecamatan yang ada di Kabupaten Gorontalo memiliki warna yang sama yakni merah muda, artinya tidak ada Kecamatan yang memiliki kejadian DBD tinggi IR $>55$ per 100.000 penduduk yang disimbolkan dengan warna merah maupun sedang IR $>22$ dan $<55$ per 100.000 penduduk yang disimbolkan dengan warna merah kecoklatan.

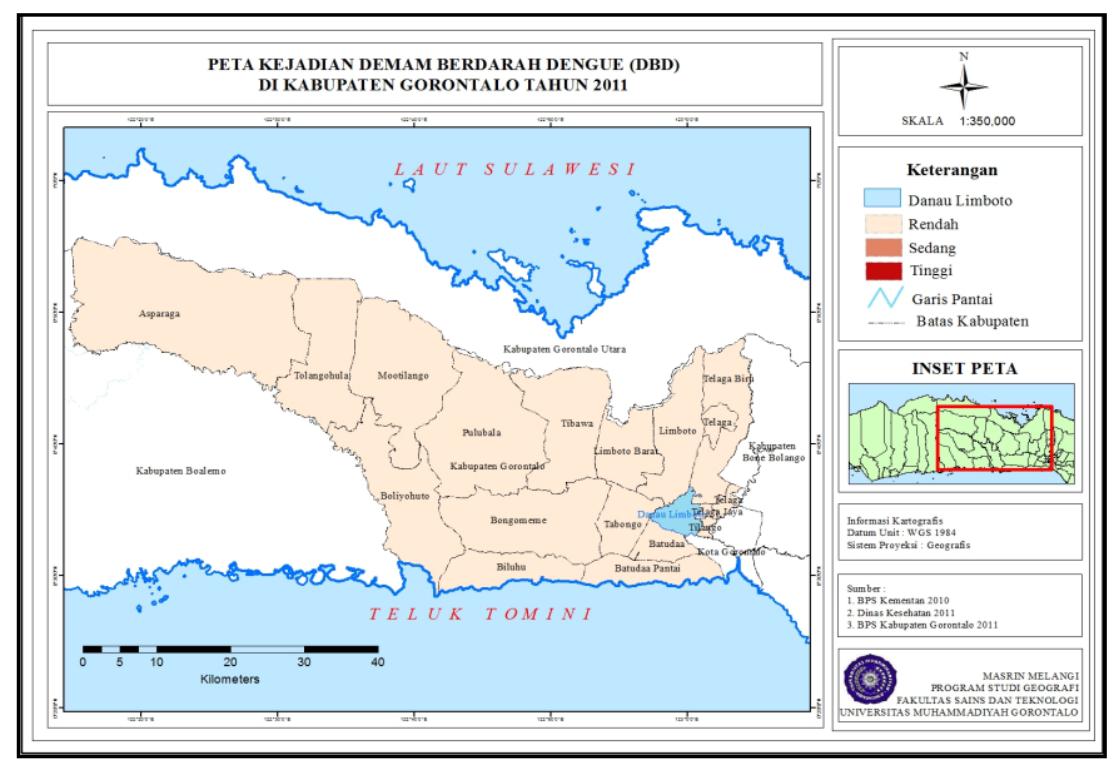

Gambar 2. Peta Kejadian DBD Tahun 2011

\section{Kejadian DBD Tahun 2012}

Berdasarkan data sekunder yang diperoleh melalui analisis secara statistik dan spasial dapat dilihat pada Tabel 3 berikut ini:

Tabel 3. Angka kejadian DBD Tahun 2012

\begin{tabular}{|l|c|c|l|}
\hline \multirow{2}{*}{ Kecamatan } & \multirow{2}{*}{ IR DBD } & \multicolumn{2}{c|}{ Curah Hujan (mm/tahun) } \\
\cline { 3 - 4 } & & Rata-rata & \multicolumn{1}{c|}{ Pos Hujan } \\
\hline Limboto & 68.09 & 90.83 & Stasiun Geofisika \\
\hline Limboto Barat & 7.6 & 166.17 & Stasiun Djalaludin \\
\hline Telaga Biru & 19.96 & 90.83 & Stasiun Geofisika \\
\hline Telaga Jaya & 0 & 90.83 & Pos Hujan Tilango \\
\hline Telaga & 17.27 & 128.83 & Pos HujanTelaga \\
\hline Tilango & 47.2 & 90.83 & Pos Hujan Tilango \\
\hline Tibawa & 25.27 & 166.17 & Stasiun Djalaludin \\
\hline Tabongo & 5.2 & 90.83 & Pos Hujan TBatudaa \\
\hline Pulubala & 0 & 166.17 & Stasiun Djalaludin \\
\hline Motilango & 10.07 & 147.33 & Pos Hujan Motilango \\
\hline Boliyohuto & 0 & 248.58 & Pos Hujan Boliyohuto \\
\hline Biluhu & 0 & 155.08 & Pos Hujan Biluhu \\
\hline Asparaga & 0 & 135.75 & Pos Hujan Tolangohula \\
\hline Tolangohula & 0 & 135.75 & Pos Hujan Tolangohula \\
\hline Batudaa & 6.69 & 79.5 & Pos Hujan Batuaaa \\
\hline Batudaa Pantai & 0 & 79.5 & Pos Hujan Batuaaa \\
\hline Bongomeme & 9.81 & 197 & Pos Hujan Bongomeme \\
\hline
\end{tabular}

(Sumber: Hasil Analisis 2017) 
Tabel 3 menunjukkan bahwa ada satu Kecamatan yang memiliki IR >55 yakni Kecamatan Limboto dengan angka Kejadian 68,09 per 100.000 penduduk yang memiliki jumlah penduduk 51.397 jiwa dan $\mathrm{CH} 90,83 \mathrm{~mm} / \mathrm{tahun}$. Kecamatan yang memiliki IR > 22 dan $<55$ per 100.000 penduduk yakni Kecamatan Tibawa dengan angka Kejadian 25,27 per 100.000 penduduk, yang memiliki jumlah penduduk 43.522 jiwa dan $\mathrm{CH}$ rata-rata $166,17 \mathrm{~mm} /$ tahun yang menggunakan data Stasiun Djalaludin serta Kecamatan Tilango dengan angka Kejadian 47,2 per 100.000 penduduk yang memiliki jumlah penduduk 14.830 jiwa dan $\mathrm{CH}$ ratarata 90,83 mm/tahun yang menggunakan data Pos Hujan Tilango. Kecamatan yang memiliki IR < 22 ada tujuh Kecamatan yakni Kecamatan Telaga Biru dengan angka kejadian 19.96 per 100.000 penduduk, yang memiliki jumlah penduduk 30.053 jiwa dan $\mathrm{CH}$ rata-rata 90,83mm/tahun yang menggunakan data Stasiun Geofisika, Telaga dengan angka kejadian 17,27 per 100.000 penduduk, yang memiliki jumlah penduduk 23.155 jiwa dan $\mathrm{CH}$ rata-rata $128.83 \mathrm{~mm} /$ tahun yang menggunakan Data Pos Hujan Telaga, Motilango dengan angka kejadian 10,07 per 100.000 penduduk, yang memiliki jumlah penduduk 19.216 jiwa dan $\mathrm{CH}$ rata-rata 147,33 mm/tahun yang mengunakan Data pos Hujan Motilango, Bongomeme dengan angka kejadian 9,81 per 100.000 penduduk, yang memiliki jumlah penduduk 20.379 jiwa dan $\mathrm{CH}$ rata-rata $197 \mathrm{~mm} /$ tahun yang menggunakan data pos hujan Bongomeme, Limboto Barat dengan angka kejadian 7,63 per 100.000 penduduk, yang memiliki jumlah penduduk 26.211 jiwa dan CH rata-rata 166,17 mm/tahun menggunakan data Stasiun Djalaludin, Tabongo dengan angka kejadian 5,20 per 100.000 penduduk, yang memiliki jumlah penduduk 19.216 jiwa dan Batudaa dengan angka kejadian 6,69 per 100.000 per 100.000 penduduk, yang memiliki jumlah penduduk 14.926 jiwa dan $\mathrm{CH}$ rata-rata $79,5 \mathrm{~mm} /$ tahun yang menggunakan data pos hujan Batudaa.

Selain Kecamatan yang memiliki IR DBD rendah di Kabupaten Gorontalo terdapat tujuh Kecamatan yang memiliki IR = 0 yakni Kecamatan Telaga Jaya, Pulubala, Boliyohuto, Biluhu, Asparaga, Tolangohulam dan Batudaa Pantai yang memiliki jumlah penduduk bervariasi (Gambar3) dan jumlah $\mathrm{CH}$ rata-rata yang bervariasi serta pos hujan yang berbeda-beda. Pada Gambar 3 nampak tiga gradasi warna, terlihat 1 Kecamatan yang memiliki warna merah yang menandakan wilayah yang memiliki IR tinggi yakni Kecamatan Limboto dan Telaga Biru, dan 2 Kecamatan memiliki warna yang sama yakni merah kecoklatan yang memiliki IR sedang, serta 7 Kecamatan lainnya yang memiliki IR rendah di tandai dengan warna merah muda.

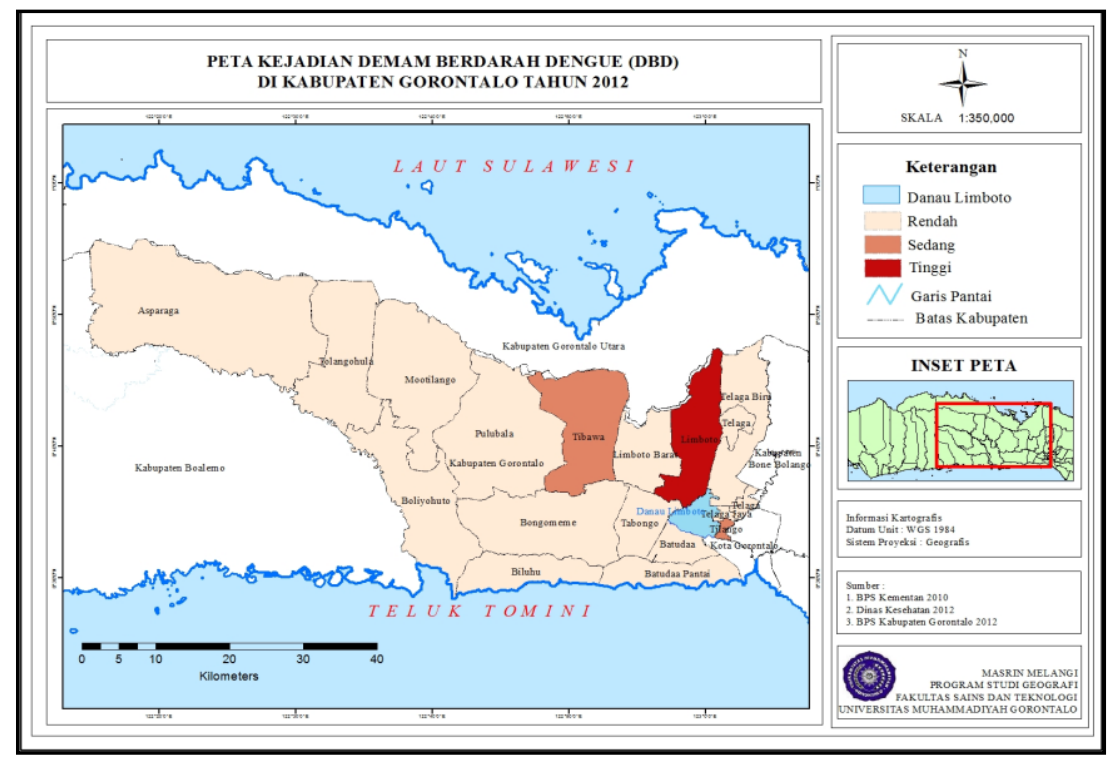

Gambar 3. Peta Kejadian DBD Tahun 2012

\section{Kejadian DBD Tahun 2013}

Berdasarkan data sekunder yang diperoleh melalui analisis secara statistik dan spasial dapat dilihat pada Tabel 4 berikut ini: 
Tabel 4. Angka kejadian DBD Tahun 2013

\begin{tabular}{|l|c|c|l|}
\hline \multirow{2}{*}{ Kecamatan } & \multirow{2}{*}{ IR DBD } & \multicolumn{2}{c|}{ Curah Hujan (mm/tahun) } \\
\cline { 3 - 4 } & & Rata-rata & \multicolumn{1}{c|}{ Pos Hujan } \\
\hline Limboto & 95,33 & 90.83 & Stasiun Geofisika \\
\hline Limboto Barat & 19,07 & 166.17 & Stasiun Djalaludin \\
\hline Telaga Biru & 139,07 & 90.83 & Stasiun Geofisika \\
\hline Telaga Jaya & 16,69 & 90.83 & Pos Hujan Tilango \\
\hline Telaga & 17,27 & 128.83 & Pos HujanTelaga \\
\hline Tilango & 40,45 & 90.83 & Pos Hujan Tilango \\
\hline Tibawa & 11,48 & 166.17 & Stasiun Djalaludin \\
\hline Tabongo & 10,4 & 90.83 & Pos Hujan Batudaa \\
\hline Pulubala & 7,61 & 166.17 & Stasiun Djalaludin \\
\hline Motilango & 0 & 147.33 & Pos Hujan Motilango \\
\hline Bilato & 0 & 248,58 & Pos Hujan Boliyohuto \\
\hline Boliyohuto & 5,67 & 248.58 & Pos Hujan Boliyohuto \\
\hline Biluhu & 0 & 155.08 & Pos Hujan Biluhu \\
\hline Asparaga & 0 & 135.75 & Pos Hujan Tolangohula \\
\hline Tolangohula & 3,99 & 135.75 & Pos Hujan Tolangohula \\
\hline Batudaa & 6,69 & 79.5 & Pos Hujan Batudaa \\
\hline Batudaa Pantai & 0 & 79.5 & Pos Hujan Batudaa \\
\hline Dungaliyo & 16,25 & 197 & Pos Hujan Bongomeme \\
\hline Bongomeme & 0 & 197 & Pos Hujan Bongomeme \\
\hline (Sumber Hasing & & & \\
\hline
\end{tabular}

(Sumber: Hasil Analis is 2017)

Pada Tabel 4 dapat dilihat bahwa kejadian DBD di Kabupaten Gorontalo terdapat di dua Kecamatan yang memiliki IR >55 per 100.000 penduduk yakni Kecamatan Limboto 95,33 per 100.000 penduduk yang memiliki jumlah penduduk 51.307 jiwa dan $\mathrm{CH}$ rata-rata 95,33 $\mathrm{mm} / \mathrm{tahun}$ yang menggunakan data Stasiun Geofisika dan Telaga Biru dengan angka kejadian 139,75 per 100.000 penduduk yang memiliki jumlah penduduk 30.053 jiwa yang menggunakan data Stasiun Geofisika, dan IR $>22$ dan $<55$ per 100.000 penduduk terdapat di Kecamatan Tilango dengan angka kejadian 40,45 per 100.000 penduduk yang memiliki jumlah penduduk 14.830 jiwa dan $\mathrm{CH}$ rata-rata 90,83 mm/ tahun menggunakan data pos hujan Tilango.

Kecamatan yang memiliki IR DBD <22 per 100.000 penduduk yakni diantaranya Kecamatan Limboto Barat dengan angka kejadian 19,07 per 100.000 penduduk, yang memiliki jumlah penduduk 26.211 jiwa dan $\mathrm{CH}$ rata-rata $166,17 \mathrm{~mm} /$ tahun yang menggunakan data stasiun Meteorologi, Telaga Jaya dengan angka kejadian 16,69 per 100.000 penduduk, yang memiliki jumlah penduduk 11.982 jiwa dan $\mathrm{CH}$ rata-rata $90,83 \mathrm{~mm} /$ tahun yang menggunakan data pos hujan Tilango, Telaga dengan angka kejadian 17,27 per 100.000 penduduk, yang memiliki jumlah penduduk 23.155 jiwa dan $\mathrm{CH}$ rata-rata $128,83 \mathrm{~mm} /$ tahun menggunakan data pos hujan Telaga. Tibawa dengan angka kejadian 11,48 per 100.000 penduduk, yang memiliki jumlah penduduk 43.522 jiwa dan $\mathrm{CH}$ rata-rata $166,17 \mathrm{~mm} /$ tahun yang menggunakan data Stasiun Meteorologi, Tabongo dengan angka kejadian 10,40 per 100.000 penduduk, yang memiliki jumlah penduduk 19.216 jiwa dan $\mathrm{CH}$ rata-rata $90,83 \mathrm{~mm} /$ tahun menggunakan data pos hujan Tilango, Pulubala dengan angka kejadian 7,61 per 100.000 penduduk yang memiliki jumlah penduduk 26.248 jiwa dan $\mathrm{CH}$ rata-rata $166,17 \mathrm{~mm} /$ tahun yang menggunkaan data stasiun Meteorologi, Asparaga dengan angka kejadian 7,05 per 100.000 penduduk, yang memiliki jumlah penduduk 1278 jiwa dan Tolangohula dengan angka kejadian 3,99 per 100.000 penduduk yang memiliki jumlah penduduk 25.011 jiwa, masing-masing memiliki $\mathrm{CH}$ rata-rata $135,75 \mathrm{~mm} /$ tahun menggunakan data pos hujan tolangohula. Kemudian Kecamatan Dungaliyo dengan angka kejadian 16,25 per 100.000 penduduk, yang memiliki jumlah penduduk 18.458 jiwa dan $\mathrm{CH}$ rata -rata $197 \mathrm{~mm} / \mathrm{tahun}$ menggunakan data pos hujan Bongomeme, serta terdapat beberapa Kecamatan lainnya yang memiliki $I R=0$. Terdapat 2 Kecamatan yang memiliki warna merah yang menandakan wilayah yang memiliki IR tinggi yakni Kecamatan Limboto dan Telaga Biru, dan nampak Kecamatan Tilango berwarna merah 
kecoklatan yang menandakan bahwa kejadian DBD pada daerah tersebut memiliki IR sedang, serta 14 Kecamatan lainnya yang memiliki IR Rendah di tandai dengan warna muda.

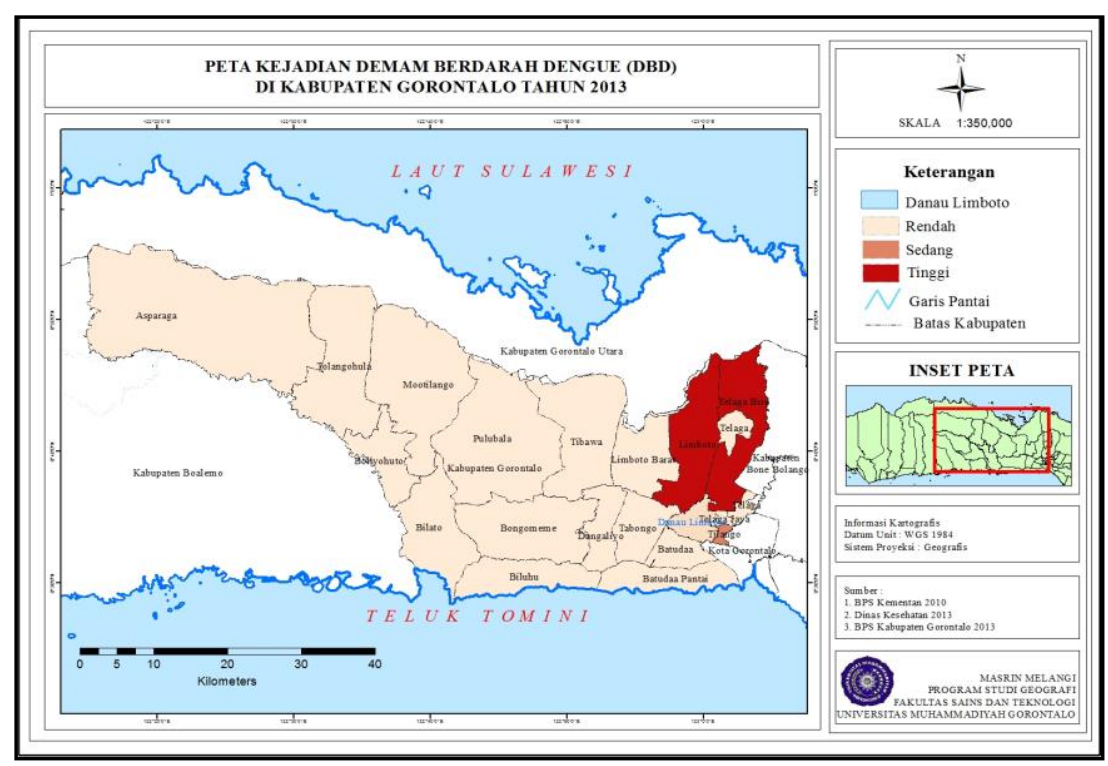

Gambar 4. Peta Kejadian DBD Tahun 2013

\section{Kejadian DBD Tahun 2014}

Berdasarkan data sekunder yang diperoleh melalui analisis secara statistik dan spasial dapat dilihat pada Tabel 5 berikut ini:

Tabel 5. Angka kejadian DBD Tahun 2014

\begin{tabular}{|l|c|c|l|}
\hline \multirow{2}{*}{ Kecamatan } & \multirow{2}{*}{ IR DBD } & \multicolumn{2}{c|}{ Curah Hujan (mm/tahun) } \\
\cline { 3 - 4 } & & Rata-rata & \multicolumn{1}{c|}{ Pos Hujan } \\
\hline Limboto & 64.7 & 99.83 & Stasiun Geofisika \\
\hline Limboto Barat & 19.1 & 106.41 & Pos Hujan Limboto Barat \\
\hline Telaga Biru & 139 & 116.75 & Pos Hujan Telaga Biru \\
\hline Telaga Jaya & 8.63 & 99.83 & Pos Hujan Tilango \\
\hline Telaga & 33 & 106 & Pos HujanTelaga \\
\hline Tilango & 40 & 99.83 & Pos Hujan Tilango \\
\hline Tibawa & 11 & 1162 & Stasiun Djalaludin \\
\hline Tabongo & 10 & 45.83 & Pos Hujan Batudaa \\
\hline Pulubala & 7.62 & 1162 & Stasiun Djalaludin \\
\hline Motilango & 10 & 118.75 & Pos Hujan Motilango \\
\hline Boliyohuto & 13.4 & 136.33 & Pos Hujan Boliyohuto \\
\hline Biluhu & 7.74 & 99.67 & Pos Hujan Biluhu \\
\hline Asparaga & 4.08 & 129.42 & Pos Hujan Tolangohula \\
\hline Tolangohula & 9.923 & 129.42 & Pos Hujan Tolangohula \\
\hline Batudaa & 22.92 & 45.83 & Pos Hujan Batuaaa \\
\hline Batudaa Pantai & 0 & 45.83 & Pos Hujan Batuaaa \\
\hline Bongomeme & 0 & 123.92 & Pos Hujan Bongomeme \\
\hline
\end{tabular}

(Sumber: Hasil Analisis 2017)

Ukuran relatif yang di hitung menggunakan angka kejadian (IR), Daerah yang memiliki IR tertinggi terdapat di Kecamatan Telaga Biru kurang lebih 139.75, dan Kecamatan Boliyohuto yang memiliki IR DBD terendah kurang lebih 5.67. Jika dilihat berdasarkan jumlah penduduk, di Kabupaten Gorontalo Daerah yang memiliki IR DBD tinggi memiliki jumlah penduduk sekitar 26.211 jiwa di bandingkan dengan Kecamatan yang memiliki IR DBD rendah memiliki jumlah penduduk yakni sekitar 17.632 Jiwa. 
Pada Tabel 5 dapat dilihat bahwa kejadian DBD di Kabupaten Gorontalo terdapat di dua Kecamatan yang memiliki IR>55 per 100.000 penduduk yakni Kecamatan Limboto dengan angka kejadian 64,7jumlah penduduk 51.008 jiwa dan $\mathrm{CH}$ rata-rata 99,83 menggunakan data Stasiun Geofisika dan Telaga Biru \pm 139 . selain itu terlihat pula pada tebel 4.5 Kecamatan yang memiliki IR >22 dan <55 per 100.000 penduduk yakni Telaga dengan angka kejadian 30,23 memiliki jumlah penduduk 23.155 jiwa dan $\mathrm{CH}$ rata-rata $106 \mathrm{~mm} /$ tahun menggunakan data pos hujan Telaga dan Kecamatan Tilango dengan angka kejadian 26,77 memiliki jumlah penduduk 14.940 jiwa dan $\mathrm{CH}$ rata-rata 99,83 mm/tahun menggunakan data pos hujan Tilango.

Kejadian DBD di Kabupaten Gorontalo tidak hanya memiliki IR tinggi ataupun sedang, terdapat pula beberapa Kecamatan yang memiliki IR rendah $(<22$ per 100.000 penduduk yakni Limboto Barat dengan angka kejadian 7,64 memiliki jumlah penduduk 26.153 jiwa dan $\mathrm{CH}$ rata-rata 106,41 menggunakan pos hujan limboto barat, Tibawa dengan angka kejadian 18,39 memiliki jumlah penduduk 43.485 jiwa dan $\mathrm{CH}$ rata-rata $114,42 \mathrm{~mm} /$ tahun menggunakan data stasiun Meteorologi, Tabongo dengan angka kejadian 5,20 memiliki jumlah penduduk 19.200 jiwa dan $\mathrm{CH}$ rata-rata $99,83 \mathrm{~mm} /$ tahun menggunakan data pos hujan tilango, Pulubala dengan angka kejadian 7,62 memiliki jumlah penduduk 26.215 jiwadan $\mathrm{CH}$ rata-rata $114,42 \mathrm{~mm} /$ tahun menggunakan data stasiun meteorologi, Batudaa dengan angka kejadian 13,40 memiliki jumlah penduduk 14.918 jiwa dan $\mathrm{CH}$ rata-rata 45,83 mm/tahun menggunakan data pos hujan Batudaa, Dungaliyo, dengan angka kejadian 10,87 memiliki jumlah penduduk 18.398 jiwa dan $\mathrm{CH}$ ratarata 123,92 mm/tahun menggunakan data pos hujan Bongomeme, dan Kecamatan Bilato dengan angka kejadian 9,92 memiliki jumlah penduduk 10.077 jiwa dan $\mathrm{CH}$ rata-rata 136,33 mm/tahun menggunakan data pos hujan Boliyohuto, selain itu terdapat beberapa Kecamatan lainnya yang memiliki $\mathrm{IR}=0$ dengan jumlah penduduk yang berbeda dan $\mathrm{CH}$ yang berbeda.

Pada Gambar 5 terlihat 2 Kecamatan yang memiliki warna merah yang menandakan wilayah yang memiliki IR tinggi yakni Kecamatan Limboto dan Telaga Biru, nampak pula Kecamatan Tilango, Biluhudan Telaga Jaya berwarna merah kecoklatan yang menandakan bahwa kejadian DBD pada daerah tersebut memiliki IR sedang, serta 13 Kecamatan lainnya yang memiliki IR Rendah di tandai dengan warna muda.

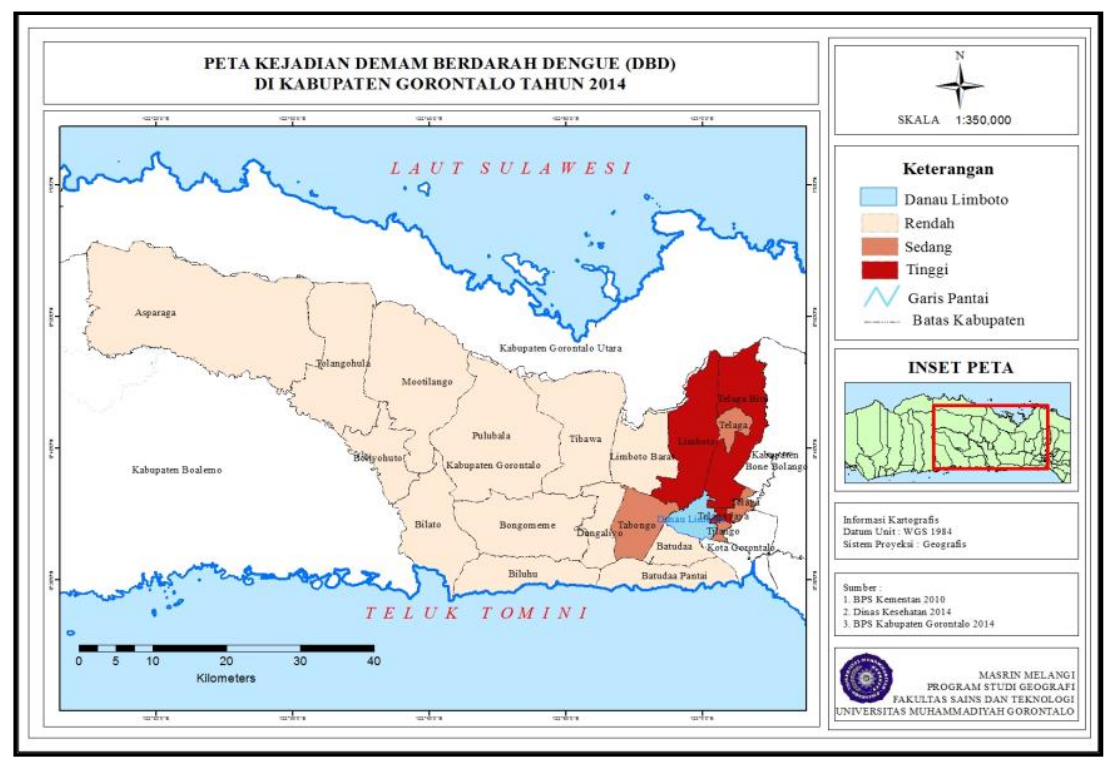

Gambar 5. Peta Kejadian DBD Tahun 2014

\section{Kejadian DBD Tahun 2015}

Berdasarkan data sekunder yang diperoleh melalui analisis secara statistik dan spasial dapat dilihat pada Tabel 6 berikut ini: 
Tabel 6. Angka kejadian DBD Tahun 2015

\begin{tabular}{|l|c|c|l|}
\hline \multirow{2}{*}{ Kecamatan } & \multirow{2}{*}{ IR DBD } & \multicolumn{2}{c|}{ Curah Hujan (mm/tahun) } \\
\cline { 3 - 4 } & & Rata-rata & \multicolumn{1}{c|}{ Pos Hujan } \\
\hline Limboto & 79,11 & 81 & Stasiun Geofisika \\
\hline Limboto Barat & 32,16 & 79.58 & Pos Hujan Limboto Barat \\
\hline Telaga Biru & 17,60 & 101.67 & Pos Hujan Telaga Biru \\
\hline Telaga Jaya & 0 & 81 & Pos Hujan Tilango \\
\hline Telaga & 61,17 & 68.92 & Pos HujanTelaga \\
\hline Tilango & 176,23 & 81 & Pos Hujan Tilango \\
\hline Tibawa & 12,15 & 71.5 & Stasiun Djalaludin \\
\hline Tabongo & 44,03 & 46.75 & Pos Hujan Batudaa \\
\hline Pulubala & 0 & 71.5 & Stasiun Djalaludin \\
\hline Motilango & 0 & 99 & Pos Hujan Motilango \\
\hline Bilato & 0 & 159,08 & Pos Hujan Boliyohuto \\
\hline Boliyohuto & 0 & 159.08 & Pos Hujan Boliyohuto \\
\hline Biluhu & 0 & 88.73 & Pos Hujan Biluhu \\
\hline Asparaga & 0 & 116.33 & Pos Hujan Tolangohula \\
\hline Tolangohula & 0 & 116.33 & Pos Hujan Tolangohula \\
\hline Batudaa & 48,98 & 46.75 & Pos Hujan Batudaa \\
\hline Batudaa Pantai & 0 & 46.75 & Pos Hujan Batuaaa \\
\hline Dungaliyo & 17,15 & 82,75 & Pos Hujan Bongomeme \\
\hline Bongomeme & 0 & 82.75 & Pos Hujan Bongomeme \\
\hline Sumber: & & & \\
\hline
\end{tabular}

(Sumber: Hasil Analis is 2017)

Berdasarkan ukuran relatif yang di hitung menggunakan angka kejadian (IR), Daerah yang memiliki IR tertinggi terdapat di Kecamatan Telaga Biru kurang lebih 167.33 per 100.000 penduduk, dan Kecamatan Tibawa yang memiliki IR DBD terendah kurang lebih 11.49 per 100.000 penduduk. Jika dilihat berdasarkan jumlah penduduk, di Kabupaten Gorontalo Daerah yang memiliki IR DBD tinggi memiliki jumlah penduduk sekitar 14.940 jiwa di bandingkan dengan Kecamatan yang memiliki IR DBD rendah memiliki jumlah lebih tinggi, yakni sekitar 43.485 Jiwa

Pada Tabel 6 dapat dilihat bahwa kejadian DBD di Kabupaten Gorontalo terdapat di tiga Kecamatan yang memiliki IR>55 per 100.000 penduduk yakni Kecamatan Limboto $\pm 79,11$ memiliki jumlah penduduk 50.559 jiwa dan $\mathrm{CH}$ rata-rata $81 \mathrm{~mm} /$ tahun menggunakan data stasiun Geofisika, Telaga dengan angka kejadian 61,17 memiliki jumlah penduduk 22.884 jiwa dan $\mathrm{CH}$ rata-rata 68,92 mm/tahun menggunakan Data pos hujan Telagadan Tilango dengan angka kejadian176,23 memiliki jumlah penduduk 1286 jiwa dan $\mathrm{CH}$ rata-rata $81 \mathrm{~mm} / \mathrm{tahun}$. Tabel 4.6 juga menunjukkan ada beberapa Kecamatan yang memiliki IR $>22$ dan $<55$ per 100.000 penduduk yakni Limoto Barat dengan angka kejadian 32,16 memiliki jumlah penduduk 24.874 jiwa dan $\mathrm{CH}$ rata-rata $79,58 \mathrm{~mm} /$ tahun menggunakan data pos hujan Limboto Barat, Tabongo dengan angka kejadian 44,03 memiliki jumlah penduduk 18.176 jiwa dan $\mathrm{CH}$ rata-rata $46,75 \mathrm{~mm} /$ tahun menggunakan data pos hujan Batudaa dan Kecamatan Batudaa dengan angka kejadian 48,98 memiliki jumlah penduduk 1490 jiwa dan $\mathrm{CH}$ rata-rata $46,75 \mathrm{~mm}$ tahun menggunakan data pos hujan batudaa.

Tabel 6 juga menunjukkan terdapat beberapa Kecamatan yang memiliki IR $<22$ per 100.000 penduduk yakni Telaga Biru dengan angka kejadian 17,60 memiliki jumlah penduduk 28.395 jiwa dan $\mathrm{CH}$ rata-rata 101,67 mm/tahun menggunakan data pos hujan Telaga Biru, Tibawa dengan angka kejadian 12,15 memiliki jumlah penduduk 41.147 jiwa dan $\mathrm{CH}$ rata-rata $71,5 \mathrm{~mm} /$ tahun menggunakan data stasiun Meteorologi, dan Ke angka kecamatan Dungaliyo dengan angka kejadian 17,15 memiliki jumlah penduduk 17.484 jiwa dan $\mathrm{CH}$ rata-rata 82,75 $\mathrm{mm} / \mathrm{tahun}$ menggunakan data pos hujan Bongomeme. Angka kejadian DBD selain di sajikan dalam bentuk tabular, disajikan pula secara spasial seperti Gambar 6 di bawah ini. Pada Gambar 6 terdapat 3 gradasi warna yang Nampak. terlihat 3 Kecamatan yang memiliki warna merah yang menandakan wilayah yang memiliki IR tinggi yakni Kecamatan Limboto, Telaga, dan 
Tilango. nampak pula Kecamatan Tabongo, Batudaa, dan Limboto Barat berwarna merah kecoklatan yang menandakan bahwa kejadian DBD pada daerah tersebut memiliki IR sedang, serta 11 Kecamatan lainnya yang memiliki IR Rendah di tandai dengan warna merah muda.

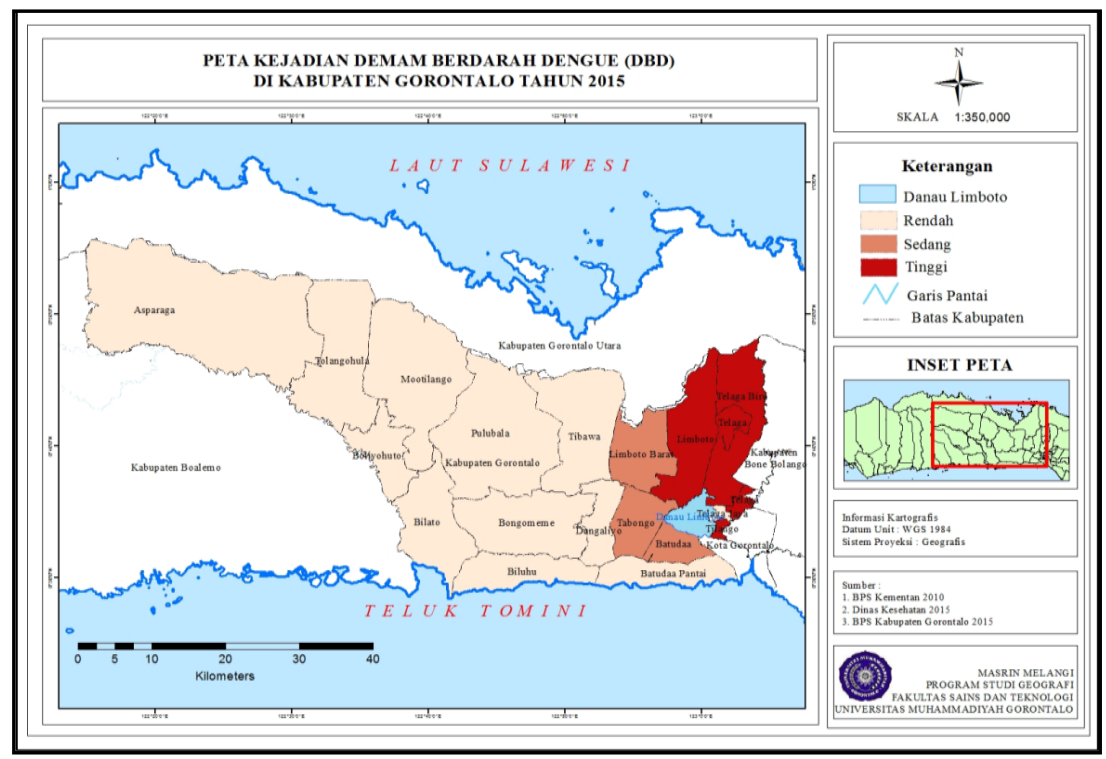

Gambar 6. Peta Kejadian DBD Tahun 2015

\section{Kejadian DBD Tahun 2016}

Berdasarkan data sekunder yang diperoleh melalui analisis secara statistik dan spasial dapat dilihat pada Tabel 7 berikut ini:

Tabel 7. Angka kejadian DBD Tahun 2016

\begin{tabular}{|l|c|c|l|}
\multirow{2}{*}{ Kecamatan } & \multirow{2}{*}{ IR DBD } & \multicolumn{2}{c|}{ Curah Hujan (mm/tahun) } \\
\cline { 3 - 4 } & & Rata-rata & \multicolumn{1}{c|}{ Pos Hujan } \\
\hline Limboto & 136.91 & 149 & Stasiun Geofisika \\
\hline Limboto Barat & 112.2 & 143.33 & Pos Hujan Limboto Barat \\
\hline Telaga Biru & 127.9 & 139.1 & Pos Hujan Telaga Biru \\
\hline Telaga & 128.4 & 845 & Pos Hujan Telaga \\
\hline Telaga Jaya & 57.63 & 149 & Pos Hujan Tilango \\
\hline Tibawa & 85.82 & 142 & Stasiun Djalaludin \\
\hline Tabongo & 63.56 & 58.27 & Pos Hujan Batudaa \\
\hline Pulubala & 11.45 & 142 & Stasiun Djalaludin \\
\hline Motilango & 0 & 90.83 & Pos Hujan Motilango \\
\hline Batudaa & 48.98 & 58.27 & Pos Hujan Batudaa \\
\hline Bongomeme & 36.7 & 143.33 & Pos Hujan Bongomeme \\
\hline Tolangohula & 17.78 & 99.42 & Pos Hujan Tolangohula \\
\hline Boliyohuto & 26.33 & 88.08 & Pos Hujan Biluhu \\
\hline Biluhu & 0 & 88.08 & Pos Hujan Biluhu \\
\hline Asparaga & 14.52 & 99.42 & Pos Hujan Tolangohula \\
\hline Batudaa Pantai & 0 & 58.27 & Pos Hujan Batudaa \\
\hline Tilango & 247.178 & 149 & Pos Hujan Tilango \\
\hline (Sumber: & & & \\
\hline
\end{tabular}

(Sumber: Hasil Analisis 2017)

Berdasarkan ukuran relatif yang di hitung menggunakan angka kejadian (IR), Daerah yang memiliki IR tertinggi terdapat di Kecamatan Tilango 247.18 per 100.000 penduduk, dan Kecamatan Pulubala yang memiliki IR DBD terendah kurang lebih 11,45 per 100.000 penduduk. Jika dilihat berdasarkan jumlah penduduk, di Kabupaten Gorontalo Daerah yang memiliki IR DBD tinggi memiliki jumlah penduduk sekitar 14.969 jiwa di bandingkan dengan 
kecamatan yang memiliki IR DBD rendah justru memiliki jumlah penduduk lebih tinggi, yakni sekitar 26.196 Jiwa

Pada Tabel 7. dapat dilihat bahwa kejadian DBD di Kabupaten Gorontalo terdapat di sembilan Kecamatan yang memiliki IR $>55$ per 100.000 penduduk yakni Kecamatan Limboto dengan angka kejadian136,91 memiliki jumlah penduduk 48.207 jiwa dan $\mathrm{CH}$ rata-rata149 $\mathrm{mm} /$ tahun menggunakan data stasiun Geofisika, Limboto Barat112,20 memiliki jumlah penduduk 25.846 jiwa dan $\mathrm{CH}$ rata-rata 143,33 mm/tahun menggunakan data pos hujan Limboto Barat, Telaga Biru 127.89 memiliki jumlah penduduk 28.930 dan $\mathrm{CH}$ rata-rata 139,1 $\mathrm{mm} /$ tahun menggunakan data pos hujan Telaga Biru, Telaga dengan angka kejadian 128.41 memiliki jumlah penduduk 22.584 jiwa dan $\mathrm{CH}$ rata-rata $, 84,25 \mathrm{~mm} /$ tahun menggunakan data pos hujan Telaga, Telaga Jaya dengan angka kejadian 57.63 memiliki jumlah penduduk 12.147 jiwa dan $\mathrm{CH}$ rata-rata $149 \mathrm{~mm} /$ tahun menggunakan data pos hujan Tilango, Tibawa dengan angka kejadian 85.82 memiliki jumlah penduduk 40.782 jiwa dan $\mathrm{CH}$ rata-rata $142 \mathrm{~mm} / \mathrm{tahun}$ menggunakan data stasiun Meteorologi, Tabongo dengan angka kejadian 63,56 memiliki jumlah penduduk 18.879 jiwa dan $\mathrm{CH}$ rata-rata $58,27 \mathrm{~mm} /$ tahun menggunakan data pos hujan Batudaa, Bilato dengan angka kejadian 70,78 memiliki jumlah penduduk 9.889 jiwa dan $\mathrm{CH}$ rata-rata $88,08 \mathrm{~mm} /$ tahun menggunakan pos hujan Biluhu dan Tilango dengan angka kejadian 247,18 memiliki jumlah penduduk 14.969 jiwa dan $\mathrm{CH}$ rata-rata $149 \mathrm{~mm} /$ tahun menggunakan data pos hujan Tilango. Pada tabel 7 terlihat pula Kecamatan yang memiliki IR $>22$ dan $<55$ per 100.000 penduduk yakni Batudaa dengan angka kejadian 48.83 memiliki jumlah penduduk 1533 jiwa dan $\mathrm{CH}$ rata-rata $58,27 \mathrm{~mm} /$ tahun menggunakan data stasiun Batudaa, Dungaliyo dengan angka kejadian 28,44 memiliki jumlah penduduk 17.577 jiwa dan $\mathrm{CH}$ rata-rata 143,33 mm/tahun menggunakan data pos hujan Bongomeme, dan Boliyohuto dengan angka kejadian 23.96 memiliki jumlah penduduk 16.688 jiwa dan $\mathrm{CH}$ rata-rata $88,08 \mathrm{~mm} /$ tahun menggunakan data Pos hujan biluhu, dan terdapat beberapa Kecamatan yang memiliki IR $<22$ per 100.000, terdapat pada 6 Kecamatan. Pada Gambar 7 terlihat 8 Kecamatan yang memiliki warna merah yang menandakan wilayah yang memiliki IR tinggi, nampak pula 3 Kecamatan berwarna merah kecoklatan yang menandakan bahwa kejadian DBD pada daerah tersebut memiliki IR sedang, serta terdapat 6 Kecamatan lainnya yang memiliki IR Rendah di tandai dengan warna merah muda.

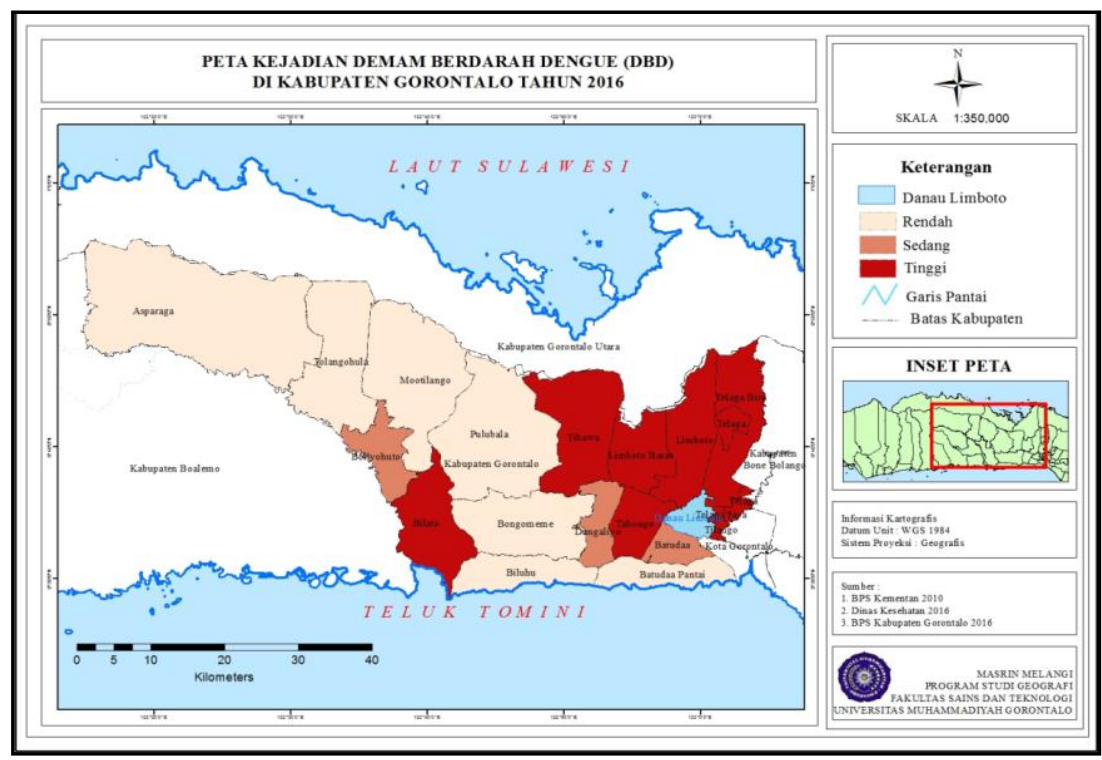

Gambar 7. Peta Kejadian DBD Tahun 2016

\section{Analisis Kejadian DBD secara Spasio-temporal}

Berdasarkan hasil penelitian diperoleh informasi perkembangan jumlah penduduk Kabupaten Gorontalo setiap tahunnya selalu mengalami peningkatan sejak Tahun 2010-2016. Hal tersebut searah dengan perkembangan kasus DBD Tahun 2010-2012 dengan Angka Kejadian (IR) DBD selama 3 tahun, cenderung mengalami penurunan, tetapi pada tahun 20132016 kembali meningkat (Gambar 8). 


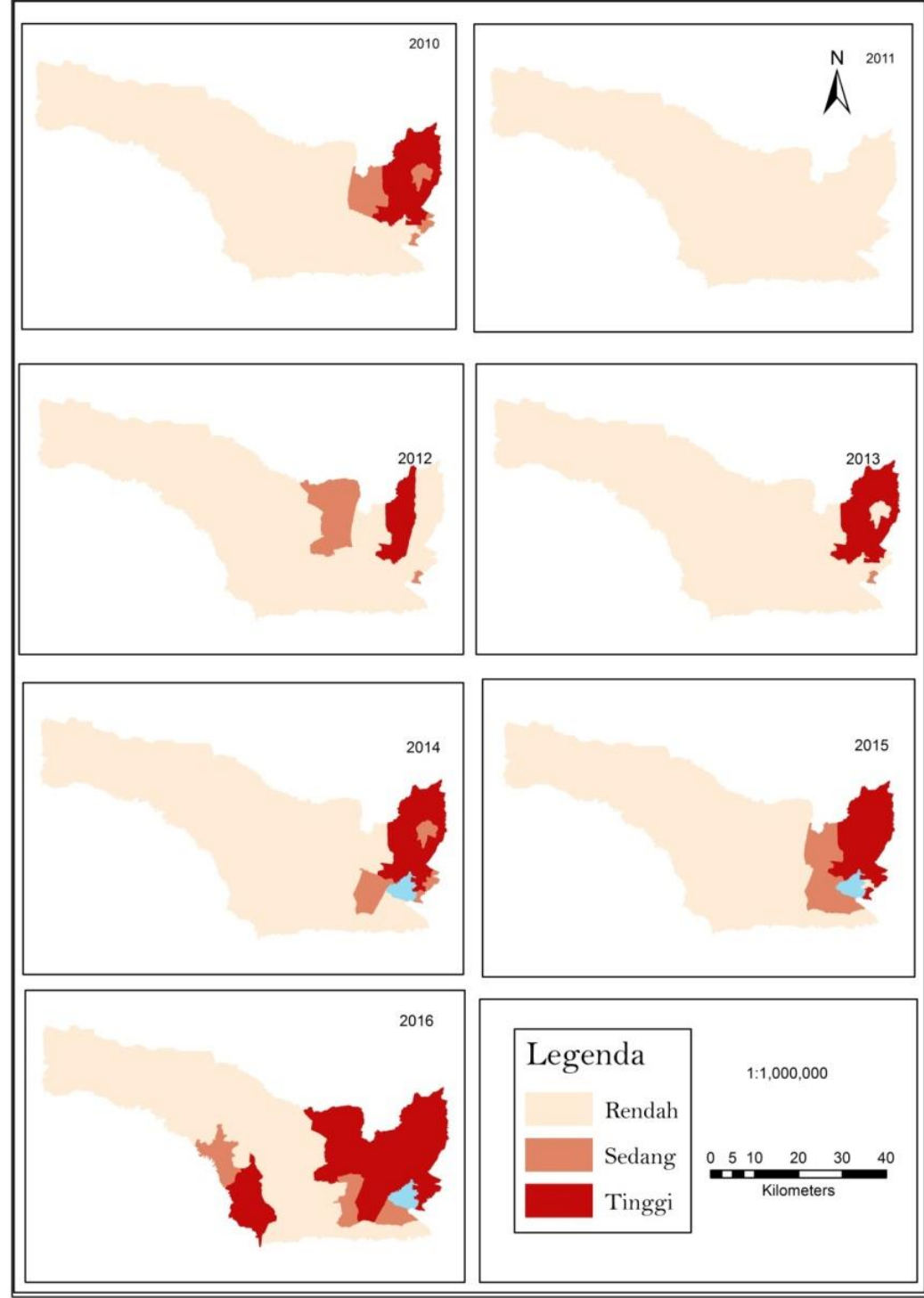

Gambar 8. Peta Spasiotemporal Kejadian DBD Tahun 2010-2016

Berikut dapat dilihat distribusi Daerah Kabupaten Gorontalo yang memiliki angka Insiden Rate DBD terendah dan tertinggi selama 6 tahun terakhir (2010-2016) (Tabel 8):

Tabel 8. Insiden Rate DBD di Daerah Kabupaten Gorontalo Tahun 2010-2016

\begin{tabular}{|l|c|}
\hline Tahun & Insiden Rate \\
\hline $\mathbf{2 0 1 0}$ & 45.91 \\
\hline $\mathbf{2 0 1 1}$ & 1.1 \\
\hline $\mathbf{2 0 1 2}$ & 19.6 \\
\hline $\mathbf{2 0 1 3}$ & 33.4 \\
\hline $\mathbf{2 0 1 4}$ & 25.8 \\
\hline $\mathbf{2 0 1 5}$ & 31.04 \\
\hline $\mathbf{2 0 1 6}$ & 77.2 \\
\hline
\end{tabular}

(Sumber: Hasil Analisis 2017)

Kecamatan di Kabupaten Gorontalo berjumlah 17 Kecamatan, setiap tahunnya Daerah ini memiliki kasus DBD dengan IR DBD tinggi, pada Tahun 2010 hingga 2016 nampak jelas pada Gambar 4.8 setiap tahunnya Kecamatan Limboto sering mengalami IR DBD tinggi kecuali pada 
tahun 2011, adapun Tahun 2010, 2013, Tahun 2014 dan Tahun 2016 Kecamatan Telaga Biru nampak berwarna merah yang artinya tahun ini Kecamatan Telaga Biru berdasarkan hasil analisis, baik statistik maupun spasial memiliki IR DBD tinggi meskipun setiap tahunnya perkembangan kasus lebih banyak di Kecamatan Limboto, akan tetapi berdasarkan analisis tersebut pada dalam waktu 3 tahun Kecamatan Telaga Biru merupakan daerah dengan Angka Kejadian tertinggi. Selain itu terdapat beberapa Kecamatan lainnya seperti Limboto Barat, Telaga Jaya, Telaga, Tabongo, Tibawa, Tilango. Dan beberapa diantaranya sering memiliki IR DBD sedang dan bahkan rendah. di Tahun 2015-2016 Kecamatan Tilango memiliki nilai angka kejadian tertinggi dari tahun sebelumnya.

\section{KESIMPULAN/CONCLUTIONS}

Berdasarkan hasil penelitian dan pembahasan di atas, maka dapat di simpulkan bahwa dalam enam tahun terakhir, sejak Tahun 2010 hingga Tahun 2016 Kabupaten Gorontalo mengalami KLB DBD di Kecamatan Limboto. Ada beberapa Kecamatan lainnya yang mengalami KLB DBD dalam waktu tiga Tahun yakni Kecamatan Telaga, Telaga Jaya, Telaga Biru, Limboto Barat, Tilango, Tibawa, dan Tabongo, hal ini ditandai karena setiap tahunnya ada yang meninggal akibat DBD, Tidak hanya itu KLB DBD di Kabupaten Gorontalo pula ditandai oleh peningkatan kasus pada setiap tahun yang mengelompok di Wilayah bagian Timur atau tepatnya berada di Area Kawasan Danau Limboto Kabupaten Gorontalo yang nampak pada Peta Spasiotemporal Kejadian DBD, dari tabel-tabel yang telah di paparkanpun dapat dilihat bahwa terdapat satu tahun, Daerah Kecamatan DBD tidak hanya karena berada di Kawasan Danau tetapi juga di pengaruhi oleh $\mathrm{CH}$ yakni pada pada Tahun 2016 selebihnya tidak ada pengaruh yang disebabkan oleh $\mathrm{CH}$ yang tinggi.

\section{DAFTAR PUSTAKA}

Achmadi, U. F. 2010. Manajemen Demam Berdarah Berbasis Wilayah. Buletin Jendela Epidemiologi . Vol. 2. ISSN-2087-1546. Hal. 4

Akib, B.D. 2014. Buku Data Status Lingkungan Hidup Daerah Kabupaten Gorontalo tahun 2014. Pemerintah Kabupaten Gorontalo: Gorontalo

Badan Pusat Statistik. 2016. Kabupaten Gorontalo dalam Angka tahun 2016. BPS.: Gorontalo

Faiz, N, Rahmawati. R, \& Safitri. 2011. Analisis Spasial Penyebaran Penyakit Demam Berdarah Dengue dengan Indeks Moran dan Geary's C (Studi Kasus di Kota Semarang Tahun 2011). Jurnal Gaussian Vol. 2Hal.2 .

Farahiyah, M., Nurjazuli, \& Setiani, O. 2014. Analisis Spasial Faktor Lingkungan dan Kejadian DBD di Kabupaten Demak. Buletin Penelitian Kesehatan,Vol. 42. Hal. 26

Hapsari, I. P. 2008. Analisis Spasiotemporal Kasus Tuberculosis di Kota Semarang Bulan Januari-Juni 2008. Semarang: Fakultas Kedokteran Universitas Diponegoro.

Harry, F. 2010. Pemanfaatan Medical Geography Berbasis Sistem Informasi Geografis Untuk Mencegah Penyebaran DBD.

Irwansyah, E. 2013. Sistem Informasi Geografis : Prinsip Dasar dan Pengembangan Aplikasi. Yogyakarta: Digibooks.

KEMENKES RI. 2011. Survey Entomologi Demam Berdarah Dengue.

Kusumadewi, S., Fauzijah, A., Arwan, A., Khoiruddin, Fathul, W., \& M, A. 2009. Informatika Kesehatan . Yogyakarta: Graha Ilmu.

Kusuma, A. P., \& Dyah, M. 2016. Analisis Spasial Kejadian Demam Berdarah Dengue Berdasarkan Kepadatan Penduduk. Unnes Journal of Public Health(UJPH) 5 (1) (2016. Hal. 50

Maria, I., Hasanuddin, I., \& Makmur, S. 2013. Faktor Risiko Kejadian Demam Berdarah Dengue (DBD) di Kota Makassar Tahun 2013. Makassar: UNHAS.

Masrizal, \& Nova, S. P. 2015. Analisis Kasus DBD Berdasarkan Unsur Iklim dan Kepadatan Penduduk Melalui Pendekatan GIS di Tanah Datar. Jurnal .

Nucifera, F., \& Nurjani, E. 2011. Kajian Spasial dan Temporal Penyakit Demam Berdarah Dengue (DBD) di Kota Yogyakarta Tahun 2004-2010. Simposium II 2011 Membangun Informasi Geospasial Untuk Pengelolaan Dan Pengembangan Wilayah .

Prahasta, E. 2009. Sistem Informasi Geografis Konsep-Konsep Dasar (Perspektif Geodesi dan Geomatika). Bandung: Informatika. 
Republik Indonesia (RI), 2011. Undang-undang No.4 Tahun Tentang Informasi Geospasial. Ruliansyah, A. 2010. Perspektif Keruangan (Geospasial) dalam melihat Fenomena Demam Berdarah Dengue. Jurnal Aspirator. Vol. 2. Hal. 19

Sari, L. 2011. Hubungan Faktor-Faktor Iklim dengan Kejadian Penyakit DBD (Demam Berdarah Dengue) di Kabupaten Cilacap Tahun 1998-2010. Semarang : Universitas Diponegoro.

Supratman, S. 2010. Masalah Vektor Demam Berdarah Dengue dan Pengendaliannya di Indonesia. Buletin Jendela Epidemiologi 2010, 2.

Suwirno, M. I. (Wawancara). 2017. Badan Meteorologi, Klimatologi dan Geofisika Gorontalo

Widiyono. 2008. Penyakit Tropis : Epidemiologi, Penularan,Pencegahan dan Pemberantasannya. Jakarta: Erlangga.

Wirayoga, \& Mustazahid, A. 2013. Hubungan Kejadian Demam Berdarah Dengue Dengan Iklim Di Kota Semarang Tahun 2006-2011. UJPH, 2 (ISSN 2252-6528).

World Health Organization. 2015. The dengue strategic plan for the Asia Pacific Region 20082015. . The Dengue Strategic Plan For the Asia Pacific Region 2008-2015.

Yusnia, S. 2010. Analisis Spasitemporal Kasus DBD di Kecamatan Tembalang Bulan JanuariJuni 2009. Fakultas Kedokteran Universitas Diponegoro:Semarang 